\title{
Artificial tears potpourri: a literature review
}

This article was published in the following Dove Press journal:

Clinical Ophthalmology

31 July 2014

Number of times this article has been viewed
Abstract: Numerous brands and types of artificial tears are available on the market for the treatment of dysfunctional tear syndrome. Past literature has focused on comparing the components of these products on patient's clinical improvement. The wide array of products on the market presents challenges to both clinicians and patients when trying to choose between available tear replacement therapies. Different formulations affect patients based on etiology and severity of disease. In order to provide an unbiased comparison between available tear replacement therapies, we conducted a literature review of existing studies and National Institutes of Health clinical trials on commercially available, brand name artificial tears. Outcomes evaluated in each study, as well as the percent of patients showing clinical and symptomatic improvement, were analyzed. Fifty-one studies evaluating different brands of artificial tears, and their efficacy were identified. Out of the 51 studies, 18 were comparison studies testing brand name artificial tears directly against each other. Nearly all formulations of artificial tears provided significant benefit to patients with dysfunctional tear syndrome, but some proved superior to others. From the study data, a recommended treatment flowchart was derived.

Keywords: dry eye, tear film, dysfunctional tear syndrome, ophthalmic lubricant, artificial tears, lipid layer, tear osmolarity, TBUT, Systane ${ }^{\circledR}$, Refresh $^{\circledR}$, Blink $^{\circledR}$, GenTeal $^{\circledR}$, Soothe ${ }^{\circledR}$, Lacrisert $^{\circledR}$, ocular surface inflammatory disease, Sjogren's Syndrome, HPMC, CMC, polyvinyl alcohol, liquid polyols

\section{Introduction}

Dysfunctional tear syndrome (DTS), commonly known as dry eye syndrome, describes the multifactorial condition where the ocular system fails to produce good quality tears or a sufficient amount of tears to keep the eye moisturized. ${ }^{1}$ Human tears, composed of electrolytes, water, proteins (eg, antibodies, lysozymes), and lipids, function to moisturize the ocular surface and minimize damage to the corneal epithelium. These components come together to form three distinct layers: 1) the outermost lipid layer, 2) a middle aqueous layer, and 3) the epithelium-covering mucoid layer. Dysfunction in any of these layers can yield tear film instability and hyperosmolarity. ${ }^{2,3}$ External causes of such dysfunction are widespread including environmental factors, systemic diseases, and medications. ${ }^{4-12}$

DTS is among the most commonly encountered ocular morbidities, affecting as many as $15 \%-25 \%$ of individuals over the age of 65 and up to $6 \%$ of adults over the age of 40. ${ }^{12-15}$ Inadequate lubrication results in ocular surface damage and discomfort. In addition to increasing the risk of ocular infection, DTS can cause irreversible scarring and fibrosis due to unprotected corneal epithelial exposure. ${ }^{16-19}$ Many clinicians have begun to treat the condition with increased vigilance. ${ }^{14}$ Furthermore, prompt intervention can offer substantial benefits with regards to quality of life and comfort. ${ }^{20}$

Artificial tears are currently the mainstay of therapy of DTS. They account for at least \$540 million in annual sales globally and are the preferred first-line therapy due to their noninvasive nature and low side effect profile. ${ }^{14,21,22}$ However, a dizzying array of brands and marketing strategies have made it a challenge for patients and clinicians alike to identify the product that best suits individual patients.
Correspondence: Majid Moshirfar Department of Ophthalmology, John A Moran Eye Center, University of Utah, 65 N Mario Capecchi, Salt Lake City, UT $84 \mid 32$, USA

$\mathrm{Tel}+\mid$ 80I 58I 2352

Fax +1 80I 58I 3357

Email majid.moshirfar@hsc.utah.edu 
Previous review articles have studied and compared the active ingredients within the artificial tears, but none have compared the full formulations available on the market. ${ }^{23}$ With a focus on artificial tear brands, this study aims to provide a useful literature-based comparison between available tear replacement therapies for clinicians and patients considering starting therapy to manage DTS. The following is a detailed overview of the commercial agents available (summarized in Tables S1-S5) for treating dry eye, with a particular emphasis placed upon those agents and practices that are most effective in mitigating symptoms of DTS.

\section{Materials and methods}

\section{Literature search}

This study involved a review of the literature analyzing artificial tear treatments of DTS. The resources utilized were the electronic databases Medline (PubMed; http://www. ncbi.nlm.nih.gov), National Institutes of Health (NIH) clinical trials (http://clinicaltrials.gov), Google Scholar, and the Cochrane Library. Keywords used in the search included dry eye, dysfunctional tear syndrome, Actimist, Advance Eye Relief, Akorn, Akwa, Blink, Clarymist, Clear Eyes, Freshkote, GenTeal, Hylogel, Isopto, Just Tears, Lacril, Lacrisert, Liposic, Lubrifresh, Murine Tears, Natural Balance, Nature's Tears, Nutratear, Oasis Tears, Paralube, Refresh, Rohto Hydra, Systane, Soothe, Tearisol, Tears Again, Tears Natural, Thera Tears, Ultra Tears, Visco Tears, and Vizulize Dry Eye Mist. Both published articles and data from clinical trials (including multicenter, blinded studies as well as open label, industryfunded studies) were included in this study. Studies were excluded if the brand and specific type of artificial tear could not be identified. Data from unpublished clinical trials and articles from artificial tears that are no longer being produced were excluded. No other exclusion criteria were applied.

The etiology of dry eye syndrome in the studies reviewed included the following conditions: environmental (humidity, pollution, etc), situational (reading/prolonged focus), contact lens wear, LASIK surgery, autoimmune syndromes, nutritional deficiencies, vitamin A, Stevens-Johnson syndrome, and irritant exposure. The patient subgroups were not excluded but were also not specifically identified in many of the studies during analysis of the treatment of DTS, and thus we cannot readily distinguish between these patient populations. In future studies, this is an issue which will need to be clearly addressed.

\section{Data compilation}

Data from all studies were compiled into one group. Each study had its own means of data collection and definition for successful treatment with artificial tears. Methods for collecting the subjective data were mainly through questionnaires including McMonnies Dry Eye Symptom survey, ${ }^{24}$ Ocular Surface Disease Index (ODSI) questionnaire, ${ }^{18}$ impact of dry eye on everyday life (IDEEL) questionnaire, ${ }^{25}$ Visual Analogue Scale, Salisbury Eye Evaluation (SEE) questionnaire, ${ }^{26}$ Ocular Discomfort Severity questionnaire, direct brand comparison with drop preference selection, quality of life through the Measure Yourself Medical Outcome Profile-2 (MYMOP2), ${ }^{27}$ and Dry Eye Disease Comfort Assessment Score. Several studies also utilized custom questionnaires. ${ }^{28-31}$ Objective data took the form of ocular surface staining using various dyes, usually fluorescein and rose bengal. Additionally, comparative data was collected through analysis of a variety of other parameters including Schirmer's test, tear break-up time, posttherapy corneal topography, tear meniscus volume, mucinous layer analysis with rose bengal staining, tear osmolarity, lipid layer thickness (LLT), improvement of visual acuity, conjunctival hyperemia, Ocular Protection Index (OPI) (examining the tear break-up time divided by the interblink interval), number of eyelid parallel conjunctival folds, blinking time analysis through the OPI 2.0 system, Global Staining Score, the TearLab Osmolarity System, and tear film normalization test (measurement of lines of improvement in visual acuity after administration of artificial tears)..$^{28,29,32-36}$

\section{Commercially available tear film substitutes}

To provide maximum utility for the patient and clinician, commercially available artificial tears were identified and categorized based on active ingredient (Tables S1-S5). Other over-the-counter treatments for DTS including gels, ointments, and sprays/mists were included in the compilation (Table S4). Active ingredients and preservatives were verified via package inserts for each product. Artificial tears were divided into groups based on active ingredients including hydroxypropyl methylcellulose (HPMC), carboxy methylcellulose (CMC), polyvinyl alcohol, homeopathic remedies, and the liquid polyols. A final group was made for other delivery methods including gel/ointments, spray/mist over-the-counter treatments, and the prescribed ophthalmic insert, Lacrisert ${ }^{\circledR}$ (Valeant, Bridgewater, NJ, USA). Lacrisert was included in the study because its composition and active ingredient mimic those of some artificial tears.

\section{Results}

A total of 18 articles comparing subjective and objective outcomes of artificial tear brands were identified in our 
literature search. All articles were written in English or translated to English from other languages, including German, Spanish, and Chinese. The outcomes from these studies are summarized in Table 1. Many of these studies utilized different parameters to determine treatment efficacy.

\section{Refresh versus Systane}

The first study compared Systane ${ }^{\circledR}$ (Alcon Laboratories, Inc., Fort Worth, TX, USA) to Refresh Tears ${ }^{\circledR}$ (Allergan, Irvine, CA, USA) in 87 patients with dry eyes over a 6 -week period. ${ }^{37}$ Both investigators and patients were blinded to the artificial tear being used. The study evaluated the conjunctival/ corneal staining and a custom symptom questionnaire at days 7, 14, 28, and 42. At days 14 and 28, patients using Systane ${ }^{\circledR}$ showed significantly improved conjunctival staining compared to patients using Refresh Tears ${ }^{\circledR}$. At days 14 and 42, patients using Systane also had significantly decreased temporal corneal staining compared to patients using Refresh. Furthermore, subjective symptomatic improvement was significantly increased in patients using Systane when compared to those using Refresh.

Another study comparing Systane versus Refresh products utilized a three-way cross-over study design comparing Systane $^{\circledR}$, Refresh Tears ${ }^{\circledR}$, and Refresh Endura ${ }^{\circledR}$ (now called Refresh Optive ${ }^{\circledR}$; Allergan). ${ }^{38}$ Including only patients with a history of dry eye signs or symptoms, 50 patients were evaluated using tear film breakup time (TBUT) and the OPI over three separate clinical visits. TBUT measurements were taken at 5, 10, 15, 20, 30, 45, and 60 minutes after tear application. Systane ${ }^{\circledR}$ significantly increased TBUT compared to both Refresh Tears $^{\circledR}$ and Refresh Endura ${ }^{\circledR}$ at 5, 10, 15, 20, and 60 minutes after artificial tear application.

A third study analyzing Refresh and Systane products compared the effects of Refresh Liquigel ${ }^{\circledR}$ and Systane ${ }^{\circledR}$ on corneal staining and symptomatic improvement in 60 patients. ${ }^{30}$ A reduced sum score of corneal staining and a reduction of corneal staining from baseline were only observed in the Refresh Liquigel ${ }^{\circledR}$ group $(P=0.008$ and $P=0.019$, respectively). Patient's tear preference and comfort were also analyzed in this study; however, patients were not blinded to the artificial tear assigned. Using one eye for each artificial tear, patient preference was recorded 5 minutes after application with $36 \%$ of patients preferring Refresh and $24 \%$ preferring Systane. Limited value may be drawn from the subjective component of this study since unilateral symptoms may have been present in the study participants.

The largest of the studies comparing artificial tears was completed in Germany. ${ }^{39}$ The study was a multicenter, observational study involving patients from 835 ophthalmologists. Data from 5,277 patients who required a change in their artificial tear formulation or were naive to artificial tear treatment were analyzed after 2-4 weeks of treatment with Refresh Optive ${ }^{\circledR}$. Patients had previously been using either Systane $^{\circledR}$, Hylo-Comod ${ }^{\circledR}$, or Lacophtal ${ }^{\circledR}$ (Ursapharm Arzneimittel GmbH, Saarbrücken, Germany). Nearly $85 \%$ of patients reported improvement in ocular comfort with Refresh Optive ${ }^{\circledR}$, and nearly $75 \%$ experienced an improvement in their symptoms after changing artificial tear treatment regimens. TBUT also significantly increased in patients using Refresh Optive ${ }^{\circledR}$ from a mean of 7.7 seconds to 10.0 seconds $(P<0.001)$.

In an industry-sponsored, Alcon, head-to-head clinical trial, visual acuity was measured after application of Systane ${ }^{\circledR}$ Ultra and Refresh Optive ${ }^{\circledR} .{ }^{36}$ The study population included 48 patients with a history of dry eye. Each patient underwent visual acuity evaluation while completing a computer task at 15,45 , and 90 minutes postapplication. The amount of time the patients maintained their best-corrected visual acuity was the measured end point. At 90 minutes, the mean time best-corrected visual acuity was maintained for 9.17 seconds with Systane versus 6.84 seconds with Refresh. These data were not statistically analyzed.

Alcon sponsored another clinical trial comparing Systane $^{\circledR}$ Ultra and Refresh Optive ${ }^{\circledR}$ with an emphasis on TBUT, corneal staining, and conjunctival staining after $0,7,14,28$, and 42 days of artificial tear use. ${ }^{40}$ A total of 109 patients with a diagnosis of dry eye were enrolled in the clinical trial with 53 in the Systane ${ }^{\circledR}$ Ultra group and 56 in the Refresh Optive ${ }^{\circledR}$ group. Mean TBUT after 42 days was 4.5 seconds with Systane ${ }^{\circledR}$ Ultra and 4.2 seconds with Refresh Optive ${ }^{\circledR}$. The study also compared corneal and conjunctival staining using a $0-10$ scale, with 0 equaling no staining present. At day 14 and 42, Systane ${ }^{\circledR}$ Ultra-treated eyes had a mean corneal staining score of 2.9 on both visits while Refresh Optive ${ }^{\circledR}$-treated eyes had a mean score of 4.5 and 4.2 for the respective visits.

\section{Refresh versus Refresh}

Allergan funded a project studying the efficacy of Refresh Tears $^{\circledR}$, Refresh Ultra ${ }^{\circledR}$, and Refresh Optive ${ }^{\circledR}$ in relieving the signs and symptoms of dry eye. ${ }^{43}$ A total of 37 participants completed the study; 18 with a history of dry eye and 19 controls without a history of dry eye. In this three-way cross-over study, each patient used each artificial tear formulation for 2 weeks while TBUT, tear evaporation, osmolarity, tear structure, and patient symptoms were evaluated. 


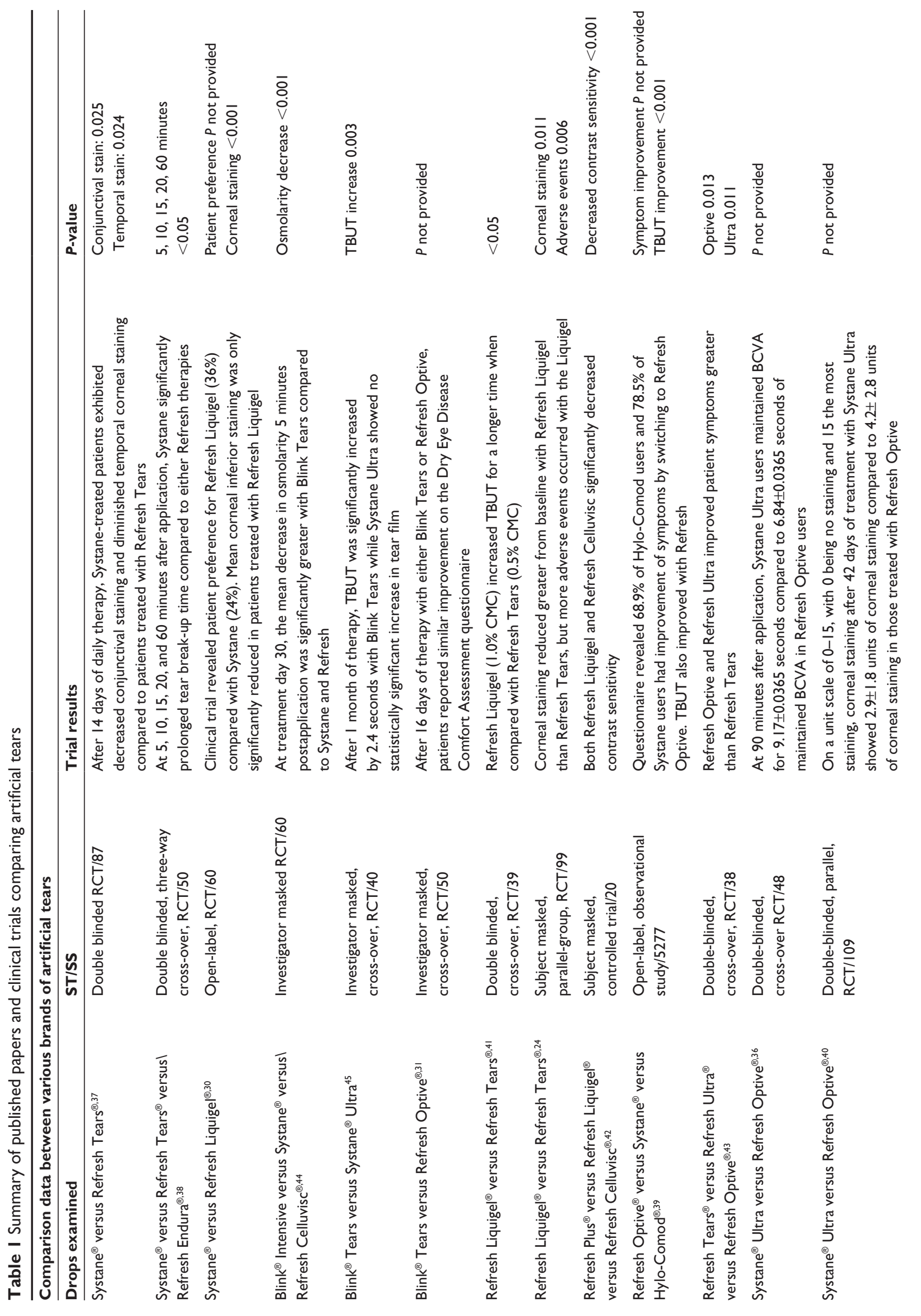




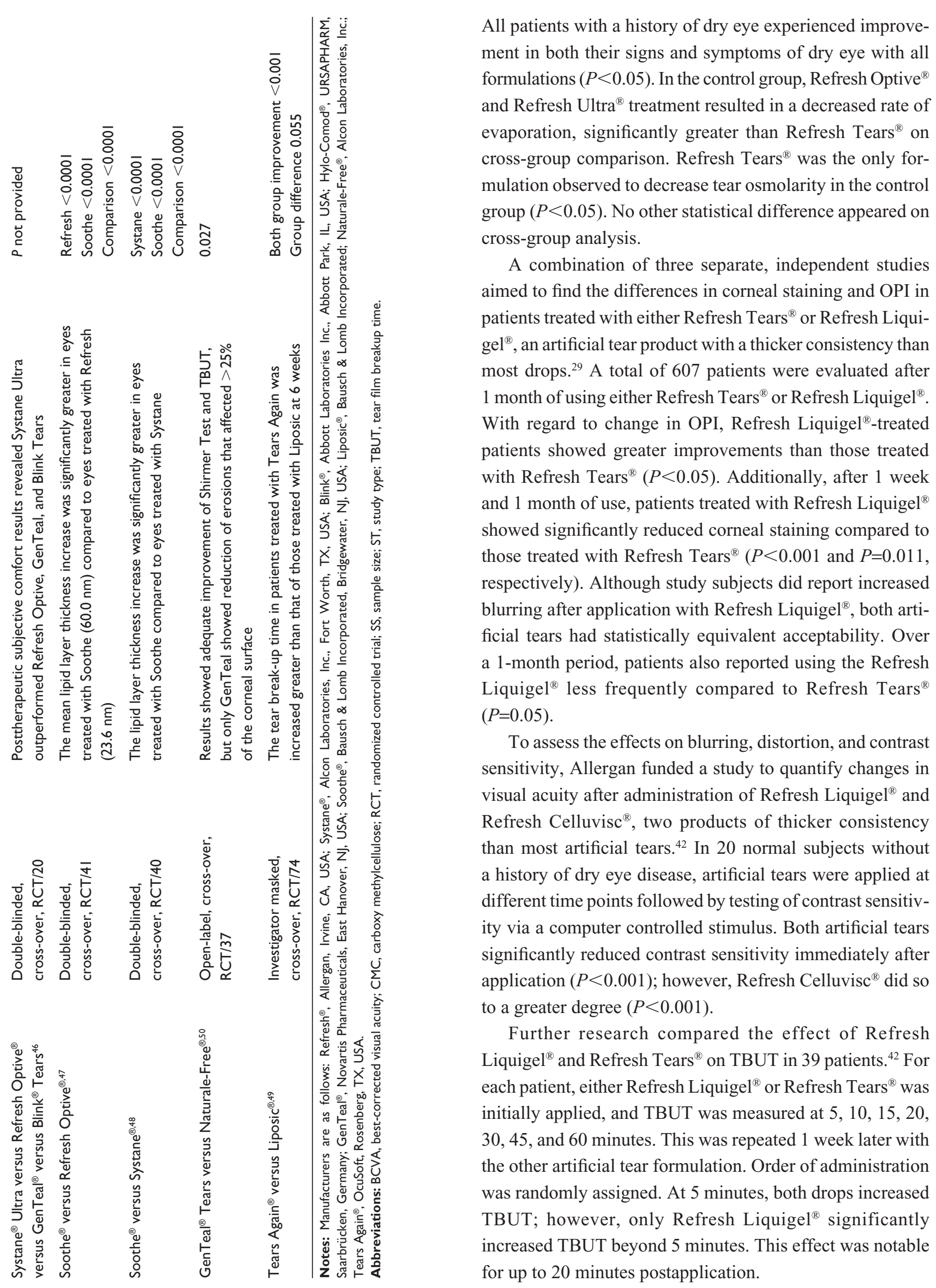




\section{Blink versus Refresh versus Systane}

In a study of 60 participants, Blink ${ }^{\circledR}$ Intensive (Abbott Laboratories, Abbott Park, IL, USA), Systane ${ }^{\circledR}$, and Refresh Celluvisc $^{\circledR}$ were compared at baseline and after 30 days of product use. ${ }^{44}$ Tear osmolarity measurement, Schirmer tear test, TBUT, fluorescein staining, corneal wavefront aberrometry, and visual acuity were all measured. All three treatment groups demonstrated improvement in all measured endpoints. However, cross-group comparison found Blink to better reduce the tear osmolarity compared to both Systane ${ }^{\circledR}$ and Refresh Celluvisc ${ }^{\circledR}(P<0.001)$. No other statistical differences were found between the groups.

One unpublished, Abbot-funded NIH clinical trial with 80 patients compared Blink ${ }^{\circledR}$ Tears to Systane ${ }^{\circledR}$ Ultra with regard to TBUT and visual acuity 1 month after treatment..$^{45}$ Blink ${ }^{\circledR}$ Tears proved superior to Systane ${ }^{\circledR}$ Ultra in both TBUT $(P=0.003)$ and improvement in visual acuity $(P<0.001){ }^{46}$

Blink $^{\circledR}$ Tears was also compared to Refresh Optive ${ }^{\circledR}$ in a trial of 51 patients with a history of dry eye. ${ }^{31}$ The primary goal of this Allergan-sponsored study was to improve subjective symptoms on the Dry Eye Disease Comfort Assessment questionnaire score over a 16-day period. No statistical analysis was performed on these data, but changes between the two groups appeared similar with a mean decrease on the questionnaire score of 1.41 with Refresh Optive ${ }^{\circledR}$ and 1.47 with Blink ${ }^{\circledR}$ Tears.

In an Alcon-sponsored clinical trial, Systane ${ }^{\circledR}$ Ultra, Refresh Optive ${ }^{\circledR}$, GenTeal Moderate ${ }^{\circledR}$ (Novartis Pharmaceuticals, East Hanover, NJ, USA), and Blink ${ }^{\circledR}$ Tears were compared with regard to postapplication comfort. ${ }^{46}$ Drop comfort grading was measured using a 0-9 scale, with 0 representing the highest level of comfort. The design was a randomized, double-masked, cross-over study with 20 patient participants. After drop administration, the comfort scores were $0.7 \pm 1.26$ for Systane ${ }^{\circledR}$ Ultra, $1.05 \pm 1.10$ for Refresh Optive $^{\circledR}, 1.84 \pm 2.19$ for Blink ${ }^{\circledR}$ Tears, and 1.1 \pm 1.21 for GenTeal ${ }^{\circledR}$. No statistical analysis was performed.

\section{Soothe versus Refresh or Systane}

Soothe ${ }^{\circledR}$ (Bausch \& Lomb Incorporated, Bridgewater, NJ, USA) is a lipid-based artificial tear. A pair of separate studies aimed to elucidate its effects on the LLT within the tear film. The first study evaluated the effectiveness of Soothe ${ }^{\circledR}$ versus Refresh Optive ${ }^{\circledR}$. Enrollment included 41 patients with a LLT under $70 \mathrm{~nm}$ in both eyes and baseline visual acuity greater than 20/70. Each patient received a drop of Soothe ${ }^{\circledR}$ in one eye and Refresh Optive ${ }^{\circledR}$ in the contralateral eye.
A custom-designed lipid layer interferometer quantified the LLT at 1, 5, and 15 minutes after application. Both artificial tears increased the LLT from a baseline of $61.5 \pm 1.6 \mathrm{~nm}$ $(P<0.001)$, with a mean LLT of $83.2 \pm 3.6 \mathrm{~nm}$ for Refresh Optive $^{\circledR}$ and $121.5 \pm 3.8 \mathrm{~nm}$ for Soothe ${ }^{\circledR}(P<0.001){ }^{47}$

A second study utilized the same inclusion criteria and study design but compared Soothe ${ }^{\circledR}$ to Systane ${ }^{\circledR}{ }^{48}$ A total of 40 patients were included in this study. Results showed a mean LLT of $124.4 \pm 4.9 \mathrm{~nm}$ for Soothe ${ }^{\circledR}$ and a mean LLT of $71.3 \pm 2.6 \mathrm{~nm}$ for Systane ${ }^{\circledR}$. This represents an increase from baseline of $107 \%$ for Soothe and only 16\% for Systane. Both studies were industry sponsored by Ocular Research (Boston, MA, USA) and Alimera Sciences (Alpharetta, GA, USA), which have partial ownership of Soothe.

\section{Other comparative studies}

Another randomized controlled study analyzing lipid-based tear substitutes looked at their effect on TBUT, Schirmer's test, tear meniscus, and subjective symptoms. ${ }^{49}$ This crossover study compared Tears Again ${ }^{\circledR}$ (OcuSoft, Rosenberg, TX, USA) to Liposic ${ }^{\circledR}$ (Bausch \& Lomb) in 74 patients with a history of dry eye over two separate 6-week periods. In both the initial treatment and after cross-over, Tears Again ${ }^{\circledR}$ improved all the aforementioned subjective and objective endpoints $(P<0.05) ; 62.5 \%$ of patients preferred Tears Again $^{\circledR}, 25 \%$ preferred Liposic ${ }^{\circledR}$, and $12.5 \%$ found the preparations to be equal.

GenTeal Tears ${ }^{\circledR}$ with preservative, GenAqua ${ }^{\circledR}$, and preservative-free Tears Naturale ${ }^{\circledR}$ (Alcon Laboratories, Inc.) were compared in an open-label, two-treatment, two-period study. ${ }^{50}$ After 4 weeks of treatment, patients were evaluated with TBUT, Schirmer's test, and corneal staining as well as via a symptom questionnaire. A total of 37 patients completed the study. Both TBUT and Schirmer testing improved in the GenTeal group but not in the Tears Naturale ${ }^{\circledR}$ group $(P=0.27)$. Both artificial tears were rated as excellent for tolerability and convenience. Subjective symptoms were not different between the two treatments.

\section{Clinical improvement}

Table 2 summarizes the clinical improvement of dry eye subjects based on objective and subjective criteria used on each study included in this review. Due to the heterogeneity of criteria used on these studies, a percent of improvement was calculated for each of the artificial tears evaluated. The percent of improvement was calculated based on the amount of subjects with symptomatic and clinical improvement with respect to the total subjects treated. 
Table 2 Clinical data for performance of artificial tears and their corresponding percent improvement based upon respective subjective and objective criteria

\begin{tabular}{|c|c|c|c|}
\hline Brand name & Pts treated (n) & Trials (n) & Improvement (\%) \\
\hline Thera Tears ${ }^{\circledR, 80}$ & 2 & 1 & 100 \\
\hline Refresh Tears $s^{\circledR, 68,37,41,54,47,70,30}$ & 739 & 7 & 100 \\
\hline Refresh Plus ${ }^{\circledR, 69,71,72,32,82,35}$ & 301 & 6 & 92.7 \\
\hline Refresh Celluvisc ${ }^{\circledast, 80}$ & II & 1 & 100 \\
\hline Refresh Liquige ${ }^{\circledast, 41,29,30,74}$ & 778 & 4 & 100 \\
\hline GenTeal ${ }^{\otimes}$ Moderate to Severe ${ }^{50}$ & 37 & I & 100 \\
\hline Lacril $^{\circledR, 81}$ & 55 & I & 100 \\
\hline Isopto ${ }^{\circledR}$ Alkaline ${ }^{80}$ & 2 & I & 100 \\
\hline Isopto ${ }^{\circledR}$ Plain $^{80}$ & 9 & I & 100 \\
\hline Blink $^{\circledR}$ Tears $^{45}$ & 20 & I & 100 \\
\hline Blink $^{\circledR}$ Intensive Tears ${ }^{75,44,90}$ & 60 & 3 & 100 \\
\hline Systane ${ }^{\circledR}$ Balance ${ }^{83,84,33}$ & 92 & 3 & 71.0 \\
\hline Systane $^{\circledR, 68,37,28,85,57,34,44,86,88,89}$ & 502 & 10 & 87.3 \\
\hline Systane $^{\circledR}$ Ultra $^{54,79,36,40}$ & 130 & 4 & 100 \\
\hline Systane $^{\circledR}$, preservative-free $^{87}$ & 27 & i & 100 \\
\hline Soothe $e^{\otimes, 47}$ & 30 & 1 & 100 \\
\hline GenTeal ${ }^{\otimes}$ Gel $^{55,56}$ & 206 & 2 & 96.0 \\
\hline Viscotears $^{\circledast, 73,80}$ & 456 & 2 & 100 \\
\hline Liposic $^{\circledast, 49}$ & 74 & I & 100 \\
\hline Refresh Lacrilube ${ }^{\circledR, 80}$ & 239 & 1 & 100 \\
\hline Tears Again ${ }^{\circledR}$ (Actimist in the UK) $)^{77,78,49}$ & 287 & 3 & 93.0 \\
\hline Refresh Optive ${ }^{\circledast, 42,36,40,31}$ & 5,430 & 4 & 75.8 \\
\hline Refresh Optive $^{\circledast}$ Sensitive ${ }^{82}$ & 114 & i & 100 \\
\hline Tears Naturale ${ }^{\circledR} \|^{80}$ & 68 & I & 100 \\
\hline Tears Naturale Free ${ }^{\circledR, 68}$ & 22 & I & 100 \\
\hline Tears Naturale ${ }^{\circledR}$ Forte ${ }^{71,76}$ & 129 & 2 & 63.0 \\
\hline
\end{tabular}

Notes: Improvement in DTS was defined in each study with the following subjective/objective criteria: subjective data: McMonnies Dry Eye Symptom survey, ODSI questionnaire, IDEEL questionnaire, SEE questionnaire, Ocular Discomfort Severity questionnaire, Direct Brand Comparison with drop preference selection, quality of life through the Measure Yourself Medical Outcome Profile-2 (MYMOP-2), Dry Eye Disease Comfort Assessment Score, and various custom questionnaires in addition to these. Objective data: McMonnies Dry Eye Symptom survey, ODSI questionnaire, IDEEL questionnaire, SEE Questionnaire, Ocular Discomfort Severity questionnaire, Direct Brand Comparison with drop preference selection, quality of life through the MYMOP-2, Dry Eye Disease Comfort Assessment Score, and various custom questionnaires in addition to these. ${ }^{23-31}$ Manufacturers are as follows: Thera Tears ${ }^{\circledR}$, Advanced Vision Research, Ann Arbor, MI, USA; Refresh ${ }^{\circledast}$, Allergan, Irvine, CA, USA; GenTeal ${ }^{\circledR}$, Novartis Pharmaceuticals, East Hanover, NJ, USA; Lacril ${ }^{\circledR}$, Allergan; Isopto ${ }^{\circledR}$, Alcon Laboratories, Inc., Fort Worth, TX, USA; Blink ${ }^{\circledR}$, Abbott Laboratories Inc., Abbott Park, IL, USA; Systane ${ }^{\circledR}$, Alcon Laboratories, Inc.; Soothe ${ }^{\circledR}$, Bausch \& Lomb Incorporated, Bridgewater, NJ, USA; Viscotears ${ }^{\circledR}$, Novartis Pharmaceuticals; Liposic ${ }^{\circledast}$, Bausch \& Lomb Incorporated; Tears Again ${ }^{\oplus}$, OcuSoft, Rosenberg, TX, USA; Tears Naturale ${ }^{\circledR}$, Alcon Laboratories, Inc.

Abbreviations: DTS, dysfunctional tear syndrome; IDEEL, impact of dry eye on everyday life; ODSI, Ocular Surface Disease Index; pts, patients.

\section{Discussion}

In all 18 head-to-head studies, patients with dry eyes had clinical improvement both immediately after application and over the long term when using tear replacements. This occurred in both preserved and preservative-free artificial tear formulations. With head-to-head comparisons, the results varied greatly and often depended on the funding source. To no surprise, each study that was industry sponsored found the respective company's artificial tear to be most effective. Further, the newer artificial tears, Refresh Optive ${ }^{\circledR}$ and Systane ${ }^{\circledR}$ Ultra, definitively outperformed the older Refresh Tears ${ }^{\circledR}$ and Systane ${ }^{\circledR}$ in both subjective and objective tests. Interestingly, Soothe ${ }^{\circledR}$ dramatically increased the lipid layer of the tear film compared to its Systane and Refresh counterparts. A lipid layer under $60 \mathrm{~nm}$ indicates a higher likelihood of having dry eye symptoms. Conversely, having a LLT greater than $75 \mathrm{~nm}$ decreases symptoms, and generally, a thicker lipid layer directly correlates with decreased symptoms. ${ }^{50}$ This is an important finding since studies have shown that a deficient lipid layer is the most common cause of DTS..$^{52}$ After reviewing all the studies, we elaborated a set of recommendations that may help both the physician and the patient in decision making when a tear replacement therapy is needed. Due to the lack of standardization and bias from industry-funded studies, these recommendations are not intended to be conclusive and final, but a good resource based on the comparative data we gathered on the discussed head-to-head studies.

\section{Recommendations}

Our recommendations for suggested drop brands in each of the respective categories is based upon both the number of studies completed on these brands as well as the trials that compared their efficacy against other brand name artificial tears (see Tables 1 and 2). Due to the heterogeneous data 
available and lack of standardization between studies, the recommendations made are not intended to be definite and should be individualized based on disease severity and patient's expectations. This is a step approach, initiating therapy with the most studied artificial tears. Treatment recommendations (summarized in Figure 1) are as follows:

\section{Step I}

The treatment algorithm allows for initial therapies to be divided into three categories of drops based on the active ingredient: CMC-based, HPMC-based, and hyaluronic acid-based. In a recent comprehensive review of the active ingredients contained in artificial tears, the above listed ingredients have been shown to be the most beneficial in improving patient comfort levels. ${ }^{53}$ For each of these categories, the most studied brands of artificial tears were recommended. Additionally, Systane ${ }^{\circledR}$ and Refresh Tears ${ }^{\circledR}$ have been well studied and have been beneficial in the treatment of mild dry eye syndrome (see Tables 1 and 2).

\section{Step 2}

Systane $^{\circledR}$ Ultra and Soothe ${ }^{\circledR}$ have both been shown in clinical research to out-perform the $\mathrm{CMC} / \mathrm{HPMC} /$ hyaluronic acid-based formulations listed in Step 1 (see Tables 1 and S1). In the instance that initial therapy fails to adequately control the symptoms of DTS, either of these two drops should be considered as the next therapy.

\section{Steps 3 and 4}

In the event that standard artificial tears fail to adequately abate the patient's symptoms and/or in the case of severe DTS, lid malposition, or exposure keratopathy, the implementation of additional therapies such as gels, ointments, liposomal sprays, is indicated. ${ }^{37,54-61}$ These therapies may need to be implemented earlier based on severity of disease.

\section{Frequency/duration}

Based on the duration and frequency of artificial tear use reported in all the studies referenced in Tables 1 and 2, a mean of 3.47 doses/day over a period 60.1 days was established. Thus, our recommendation would be to use the artificial tears three to four times per day over a period of 2 months before transitioning to the next step. If artificial tear use extends beyond four to six times per day, then a preservative-free formulation should be used. ${ }^{62}$

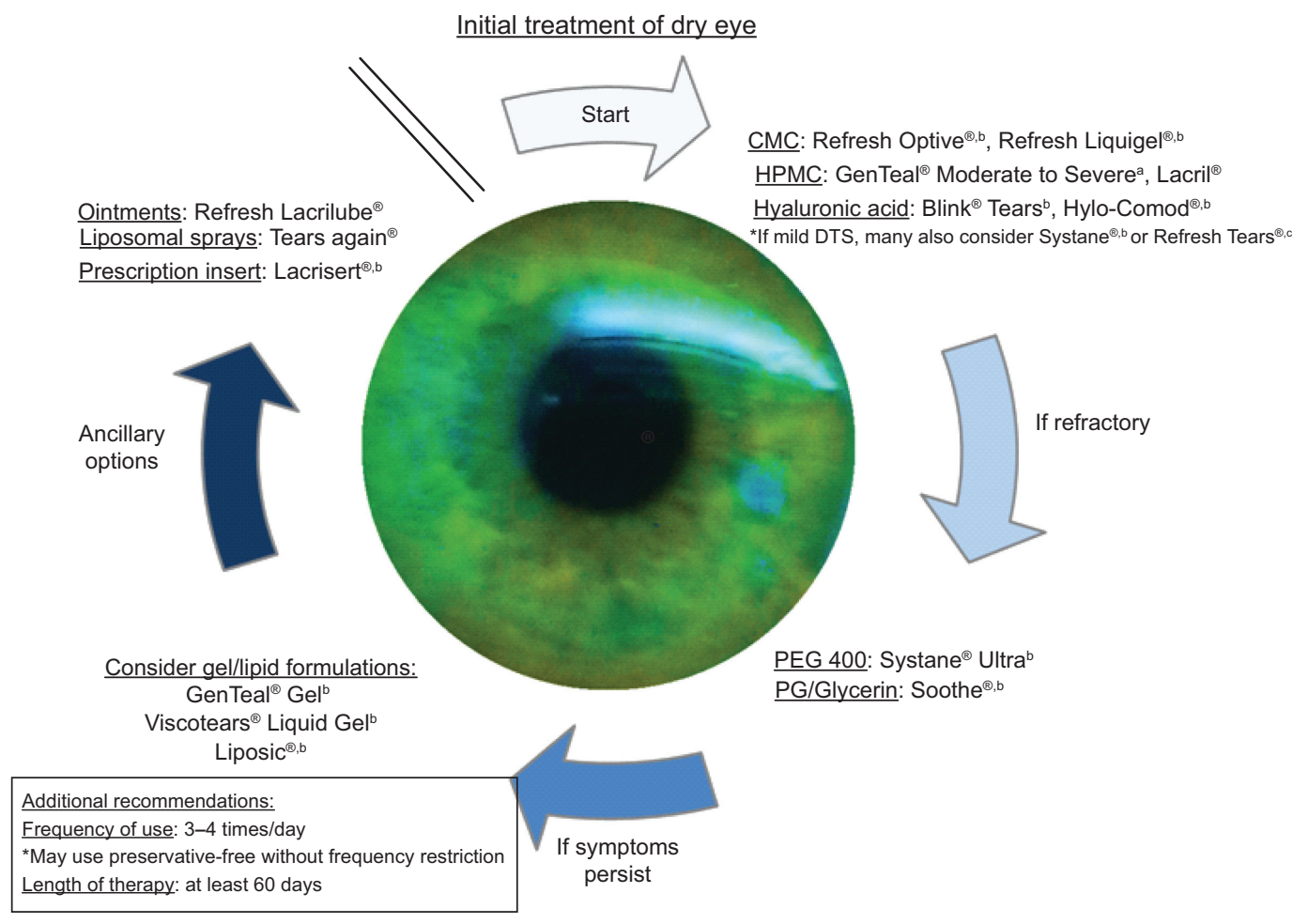

Figure I Treatment flowchart.

Notes: ${ }^{a}$ Contains $0.3 \%$ HPMC and 0.25\% CMC; 'Preservative-free option available; 'Preservative-free option: Refresh Plus ${ }^{\circledR}$. Manufacturers are as follows: Refresh ${ }^{\circledR}$, Allergan, Irvine, CA, USA; GenTea ${ }^{\circledR}$, Novartis Pharmaceuticals, East Hanover, NJ, USA; Lacril ${ }^{\circledR}$, Allergan; Blink ${ }^{\circledR}$, Abbott Laboratories Inc., Abbott Park, IL, USA; Systane ${ }^{\circledR}$, Alcon Laboratories, Inc.; Soothe ${ }^{\circledR}$, Bausch \& Lomb Incorporated, Bridgewater, NJ, USA; Viscotears ${ }^{\circledast}$, Novartis Pharmaceuticals; Liposic ${ }^{\circledR}$, Bausch \& Lomb Incorporated; Tears Again ${ }^{\circledR}$, OcuSoft, Rosenberg, TX, USA.

Abbreviations: CMC, carboxy methylcellulose; DTS, dysfunctional tear syndrome; HPMC, hydroxypropyl methylcellulose; PEG, polyethylene glycol; PG, propylene glycol. 


\section{Preserved versus preservative-free}

As seen in Tables S1-S5, many different tear replacement formulations include preservatives, but not all preservatives have the same effects. The most commonly used preservative was benzalkonium chloride (BAK). BAK has more antimicrobial activity than any other preservative in both animal and human subjects. However, BAK has been shown to damage the corneal epithelium and disrupt the tear film immediately after administration, which directly contradicts the goal of artificial tears. ${ }^{63,64}$ Some of the newer preservative compounds appear to have a better safety profile than BAK but do not entirely prevent corneal epithelium damage. ${ }^{65}$ These preservatives include Purite ${ }^{\circledR}$ (Bio-Cide International Inc., Norman, OK, USA), Polyquad ${ }^{\circledR}$ (Alcon Laboratories, Inc.), GenAqua ${ }^{\circledR}$ (Novartis Ophthalmics, East Hanover, NJ, USA), OcuPure ${ }^{\circledR}$ (Abbott Laboratories Inc.), Dissipate ${ }^{\circledR}$ (OCuSOFT, Rosenberg, TX, USA). ${ }^{50,63,66}$ Since most of the corneal changes occur when the preservatives reach high concentrations, if one chooses to use a tear replacement with preservatives, daily use should be limited to four to six times. ${ }^{62}$ Due to the risk of contamination, if a preservative-free artificial teardrop is chosen, single dose vials are recommended over multidose administration bottles. ${ }^{67}$ Increased cost represents another downside to preservative-free artificial tears compared to those with preservatives. All things considered, a choice between preservative-free and preserved artificial tears should be discussed on an individual basis between physician and patient.

\section{Limitations}

The US is currently the epicenter of clinical research on DTS as it has been previously documented to conduct $70.8 \%$ of the registered clinical trials around the world which focused on dry eye. ${ }^{23}$ The data presented in this paper may not be applicable in a global setting, as the American diet, and cultural and daily activities may play a role in the development of DTS and its corresponding treatment. With growing research in other countries, such as Japan, Australia, UK, and the Netherlands, treatment of DTS with artificial tears will progressively be refined on a global scale. ${ }^{68}$ Furthermore, the research that has been presented in this article is based on a nonregulated health product, and the US permits distribution of artificial tears without any data revealing positive efficacy ${ }^{68,37}$ Any research investments made into this field may be affected by financial interests of the investigators and call into question the integrity of the outcomes, which may have influenced our recommendations. A recent meta-analysis of the comprehensive research on dry eye disease revealed that the pharmaceutical industry sponsored $78 \%$ of 185 clinical trials on this topic in the US. ${ }^{68}$ For this reason, care should be taken when analyzing and applying data from industry-funded studies. Independent, unbiased research must increase on a worldwide level in order to more objectively and accurately elucidate the management of DTS.

In addition, this review article addressed a myriad of subjective and objective data with a multitude of data collection methods and varying result parameters, including dosing and length of treatment phase. For these reasons, further statistical analyses of improvements were not completed in this paper, but our study does suffer from lack of statistical backing. Furthermore, many of the individual papers which contributed to our information pool validated their data prior to their release. In future clinical trials, standardization of measurement instruments as well as dosage and time of treatment could enrich the generalizability of the outcomes and lead to a more consistent review of resultant data.

Finally, our study provides recommendations based on comparative studies previously published in the literature. Most of the artificial tears available in the market, as seen in Tables 2 and $\mathrm{S} 1-\mathrm{S} 5$, were not included in the recommendations since they have not been included in comparative studies. We recognize that the recommendations made are still a good guide for clinicians and patients when initiating DTS therapy based on the data available.

\section{Conclusion}

With the expansive amount of commercially available artificial tear options, specific recommendations are needed to help guide both the clinician and patient. Although limited by the lack of congruent methodology throughout the included studies and heterogeneous population, this paper aimed to provide unbiased recommendations based on the available data and should be a step towards the standardization of future studies regarding artificial tears. Utilizing both direct comparison and patient improvement following artificial tear use, a treatment flowchart was created (Figure 1). Ultimately, artificial tear selection should be individualized to the patient's specific needs. In the future, a standardized method to evaluate dry eye, as well as efficacy of artificial tear treatment, will allow for improved recommendations to be formed.

\section{Disclosure}

The authors report no conflicts of interest in this work. 


\section{References}

1. The definition and classification of dry eye disease: report of the Definition and Classification Subcommittee of the International Dry Eye WorkShop (2007). Ocul Surf. 2007;5(2):75-92.

2. Lemp MA. Contact lenses and allergy. Curr Opin Allergy Clin Immunol. 2008;8(5):457-460.

3. Tiffany J. The normal tear film. Dev Ophthalmol. 2008;41:1-20.

4. Lu P, Chen X, Liu X, et al. Dry eye syndrome in elderly Tibetans at high altitude: a population-based study in China. Cornea. 2008;27(5): 545-551.

5. Himebaugh NL, Begley CG, Bradley A, Wilkinson JA. Blinking and tear break-up during four visual tasks. Optom Vis Sci. 2009;86(2): E106-E114.

6. Wilson SE, Stulting RD. Agreement of physician treatment practices with the international task force guidelines for diagnosis and treatment of dry eye disease. Cornea. 2007;26(3):284-289.

7. Kabalak G, Dobberstein SB, Matthias T, et al. Association of immunoglobulin-like transcript 6 deficiency with Sjögren's syndrome. Arthritis Rheum. 2009;60(10):2923-2925.

8. Lerman S. Ocular side effects of acutane therapy. Lens Eye Toxic Res. 1992;9(3-4):429-438.

9. Shellans S, Rich LF, Louiselle I. Conjunctival goblet cell response to vasoconstrictor use. J Ocul Pharmacol. 1989;5(3):217-220.

10. Göbbels MJ, Achten C, Spitznas M. Effect of topically applied oxymetazoline on tear volume and tear flow in humans. Graefes Arch Clin Exp Ophthalmol. 1991;229(2):147-149.

11. Hazin R, Abuzetun JY, Daoud YJ, Abu-Khalaf MM. Ocular complications of cancer therapy: a primer for the ophthalmologist treating cancer patients. Curr Opin Ophthalmol. 2009;20(4):308-317.

12. Bjerrum KB. Keratoconjunctivitis sicca and primary Sjögren's syndrome in a Danish population aged 30-60 years. Acta Ophthalmol Scand. 1997;75(3):281-286.

13. McCarty CA, Bansal AK, Livingston PM, Stanislavsky YL, Taylor HR. The epidemiology of dry eye in Melbourne, Australia. Ophthalmology. 1998;105(6):1114-1119.

14. Latkany R. Dry eyes: etiology and management. Curr Opin Ophthal. 2008;19(4):287-291.

15. Schein OD, Muñoz B, Tielsch JM, Bandeen-Roche K, West S. Prevalence of dry eye among the elderly. Am J Ophthalmol. 1997;124(6): $723-728$.

16. Huang T, Wang Y, Liu Z, Wang T, Chen J. Investigation of tear film change after recovery from acute conjunctivitis. Cornea. 2007;26(7): 778-781.

17. Mertzanis P, Abetz L, Rajagopalan K, et al. The relative burden of dry eye in patients' lives: comparisons to a U.S. normative sample. Invest Ophthalmol Vis Sci. 2005;46(1):46-50.

18. Schiffman RM, Christianson MD, Jacobsen G, Hirsch JD, Reis BL. Reliability and validity of the Ocular Surface Disease Index. Arch Ophthalmol. 2000;118(5):615-621.

19. Vitale S, Goodman LA, Reed GF, Smith JA. Comparison of the NEIVFQ and OSDI questionnaires in patients with Sjögren's syndromerelated dry eye. Health Qual Life Outcomes. 2004;2:44.

20. Reddy P, Grad O, Rajagopalan K. The economic burden of dry eye: a conceptual framework and preliminary assessment. Cornea. 2004;23(8): 751-761.

21. Kymionis GD, Bouzoukis DI, Diakonis VF, Siganos C. Treatment of chronic dry eye: focus on cyclosporine. Clin Ophthalmol. 2008;2(4): 829-836.

22. Management and therapy of dry eye disease: report of the Management and Therapy Subcommittee of the International Dry Eye WorkShop (2007). Ocul Surf. 2007;5(2):163-178.

23. Alves M, Fonseca EC, Alves MF. Dry eye disease treatment: a systemic review of published trials and a critical appraisal of therapeutic strategies. Ocul Surf. 2013;11(3):181-192.

24. Nichols KK, Nichols JJ, Mitchell GL. The reliability and validity of McMonnies Dry Eye Index. Cornea. 2004;23(4): $365-371$.
25. Abetz L, Rajagopalan K, Mertzanis P, Begley C, Barnes R, Chalmers R; the impact of dry eye on everyday life (IDEEL) Study Group. Development and validation of the impact of dry eye on everyday life (IDEEL) questionnaire, a patient-reported outcomes (PRO) measure for the assessment of the burden of dry eye on patients. Health Qual Life Out. 2011;9:111.

26. West SK, Munoz B, Rubin GS. Function and visual Impairment in a population-based study of older adults. Invest Ophthalmol Vis Sci. 1997;38(1):72-82.

27. Kim TH, Kang JW, Kim KH, et al. Acupuncture for dry eye: a multicentre randomised controlled trial with active comparison intervention (artificial tear drop) using a mixed method approach protocol. Trials. 2010;11:107.

28. Gifford P, Evans BJ, Morris J. A clinical evaluation of Systane. Cont Lens Anterior Eye. 2006;29(1):31-40.

29. Simmons PA, Vehige JG. Clinical performance of a mid-viscosity artificial tear for dry eye treatment. Cornea. 2007;26(3): 294-302.

30. Noecker RJ. Comparison of initial treatment response to two enhancedviscosity artificial tears. Eye Contact Lens. 2006;32(3):148-152.

31. Allergan. Efficacy and acceptability of two lubricant eye drops. NLM Identifier: NCT00756678 [webpage on the Internet]. Bethesda, MD: Clinicaltrials.gov; 2008. Available from: http://clinicaltrials.gov/show/ NCT00756678. Accessed September 24, 2013.

32. Nilforoushan M, Latkany RA, Speaker MG. Effect of artificial tears on visual acuity. Am J Ophthalmol. 2005;140(5):830-835.

33. Charters L. Artificial tear normalizes blink pattern. Ophthalmology Times. July 2011.

34. Rolando M, Autori S, Badino F, Barabino S. Protecting the ocular surface and improving the quality of life of dry eye patients: a study of the efficacy of an HP-guar containing ocular lubricant in a population of dry eye patients. J Ocul Pharmacol Ther. 2009;25(3):271-278.

35. Latkany R, Lock BG, Speaker M. Tear film normalization test: a new diagnostic test for dry eyes. Cornea. 2006;25(10):1153-1157.

36. Alcon Research. The effect of systane ultra lubricant eye drops (FID112903) on visual performance. NLM Identifier: NCT00673764 [webpage on the Internet]. Bethesda, MD: Clinicaltrials.gov; 2008. Available from: http://clinicaltrials.gov/show/NCT00673764. Accessed September 24, 2013.

37. Christensen MT, Cohen S, Rinehart J, et al. Clinical evaluation of an HP-guar gellable lubricant eye drop for the relief of dryness of the eye. Curr Eye Res. 2004;28(1):55-62.

38. Ousler GW, Michaelson C, Christensen MT. An evaluation of tear film breakup time extension and ocular protection index scores among three marketed lubricant eye drops. Cornea. 2007;26(8):949-952.

39. Kaercher T, Buchholz P, Kimmich F. Treatment of patients with keratoconjunctivitis sicca with Optive: results of a multicenter, open-label observational study in Germany. Clin Ophthalmol. 2009;3:33-39.

40. Alcon Research. Evaluation of SYSTANE ultra lubricant eye drops. NLM Identifier: NCT00702377 [webpage on the Internet]. Bethesda, MD: Clinicaltrials.gov; 2008. Available from: http://clinicaltrials.gov/ ct2/show/NCT00702377. Accessed September 24, 2013.

41. Simmons $\mathrm{P}$, Vehige J. The effects of artificial tear composition on tearfilm break up time. Am Academy of Optometry. 2004; CN-00525769.

42. LaMotte JO, Ridder WH, Kuan T, Chang J, Olejnik O, Vehige J. The effect of artificial tears with different CMC formulations on contrast sensitivity. Invest Ophthalmol Vis Sci. 2002;43:E-Abstract 3151.

43. Tomlinson A, Madden LC, Simmons PA. Effectiveness of dry eye therapy under conditions of environmental stress. Curr Eye Res. 2013; 38(2):229-236.

44. Benelli U, Nardi M, Posarelli C, Albert TG. Tear osmolarity measurement using the TearLab Osmolarity System in the assessment of dry eye treatment effectiveness. Cont Lens Anterior Eye. 2010;33(2):61-67.

45. Innovative Medical. Cross-over evaluation of two lubricating eye drops. NLM Identifier: NCT00493662 [webpage on the Internet]. Bethesda, MD: Clinicaltrials.gov; 2007. Available from: http://clinicaltrials.gov/ show/NCT00493662. Accessed September 24, 2013. 
46. Alcon Research. Acute comfort and blurring profile evaluation of marketed lubricant eye drops. NLM Identifier: NCT00756093 [webpage on the Internet]. Bethesda, MD: Clinicaltrials.gov; 2008. Available from: http://clinicaltrials.gov/ct2/show/results/NCT00756093. Accessed September 24, 2013.

47. Scaffidi RC, Korb DR. Comparison of the efficacy of two lipid emulsion eyedrops in increasing tear film lipid layer thickness. Eye Contact Lens. 2007;33(1):38-44.

48. Korb DR, Scaffidi RC, Greiner JV, et al. The effect of two novel lubricant eye drops on tear film lipid layer thickness in subjects with dry eye symptoms. Optom Vis Sci. 2005;82(7):594-601.

49. Dausch D, Lee S, Dausch S, Kim JC, Schwert G, Michelson W. [Comparative study of treatment of the dry eye syndrome due to disturbances of the tear film lipid layer with lipid-containing tear substitutes]. Klin Monbl Augenheilkd. 2006;223(12):974-983. German.

50. Climent AO. Comparison of GenAqua-preserved GenTeal in multidose bottles vs preservative-free tears naturale in single dose units in patients with moderate to severe dry eye. Invest Ophthalmol Vis Sci. 2006;47: E-Abstract 261-B439.

51. Blackie CA, Solomon JD, Scaffidi RC, Greiner JV, Lemp MA, Korb DR The relationship between dry eye symptoms and lipid layer thickness. Cornea. 2009;28(7):789-794.

52. Knop E, Knop N, Millar T, Obata H, Sullivan DA. The international workshop on meibomian gland dysfunction: report of the subcommittee on anatomy, physiology, and pathophysiology of the meibomian gland. Invest Ophthalmol Vis Sci. 2011;52(4):1938-1978.

53. White CJ, Thomas CR, Byrne ME. Bringing comfort to the masses: a novel evaluation of comfort agent solution properties. Cont Lens Anterior Eye. 2014;37(2):81-91.

54. Waduthantri S, Yong SS, Tan CH, Htoon HM, Tong L. Lubricant with gelling agent in treating dry eye in adult Chinese patients. Optom Vis Sci. 2012;89(11):1647-1653.

55. Tauber J. Efficacy, tolerability and comfort of a $0.3 \%$ hypromellose gel ophthalmic lubricant in the treatment of patients with moderate to severe dry eye syndrome. Curr Med Res Opin. 2007;23(11): 2629-2636.

56. Dedhia N, et al. Efficacy and tolerability of GenTeal Gel in post-menopausal women with moderate to severe dry eye: results of a post marketing observational study. Indian Medical Gazette. 2012:186-192.

57. Hartstein I, Khwarg S, Przydryga J. An open-label evaluation of HPGuar gellable lubricant eye drops for the improvement of dry eye signs and symptoms in a moderate dry eye adult population. Curr Med Res Opin. 2005;21(2):255-260.

58. Chiambaretta F, Pouliquen P, Menerath JM, Pilotaz F, Rebika H, Rigal D. [Efficacy and safety of a fluid carbomer gel versus a conventional carbomer gel in dry eye treatment]. J Fr Ophtalmol. 2004;27(2):130-135. French.

59. Wander AH, Koffler BH. Extending the duration of tear film protection in dry eye syndrome: review and retrospective case series study of the hydroxypropyl cellulose ophthalmic insert. Ocul Surf. 2009;7(3): 154-162.

60. Hill JC. Slow-release artificial tear inserts in the treatment of dry eyes in patients with rheumatoid arthritis. Br J Ophthalmol. 1989;73(2): $151-154$.

61. Lee SY, Tong L. Lipid-containing lubricants for dry eye: a systematic review. Optom Vis Sci. 2012;89(11):1654-1661.

62. Asbell PA. Increasing importance of dry eye syndrome and the ideal artificial tear: consensus views from a roundtable discussion. Curr Med Res Opin. 2006;22(11):2149-2157.

63. Furrer P, Mayer JM, Gurny R. Ocular tolerance of preservatives and alternatives. Eur J Pharm Biopharm. 2002;53(3):263-280.

64. Charnock C. Are multidose over-the-counter artifical tears adequately preserved? Cornea. 2006;25(4):432-437.

65. Lazarus HM, Imperia PS, Botti RE, Mack RJ, Lass JH. An in vitro method which assesses corneal epithelial toxicity due to antineoplastic, preservative and antimicrobial agents. Lens Eye Toxic Res. 1989;6(1-2): 59-85.
66. Rolando M, Crider JY, Kahook MY. Ophthalmic preservatives: focus on polyquaternium-1. Expert Opin Drug Deliv. 2011;8(11): 1425-1438.

67. Kim MS, Choi CY, Kim JM, Chang HR, Chung HR, Woo HY. Microbial contamination of multiply used preservative-free artificial tears packed in reclosable containers. Br J Ophthalmol. 2008;92(11): $1518-1521$.

68. Cömez AT, Tufan HA, Kocabıyık O, Gencer B. Effects of lubricating agents with different osmolalities on tear osmolarity and other tear function tests in patients with dry eye. Curr Eye Res. 2013;38(11): 1095-1103.

69. Liu Z, Pflugfelder SC. Corneal Surface regularity and the effect of artificial tears in aqueous tear deficiency. Ophthalmology. 1999;106(5): 939-943.

70. Avunduk AM, Avunduk MC, Varnell ED, Kaufman HE. The comparison of efficacies of topical corticosteroids and nonsteroidal anti-inflammatory drops on dry eye patients: a clinical and immunocytochemical study. Am J Ophthalmol. 2003;136(4):593-602.

71. Albietz JM, Lenton LM, McLennan SG, Earl ML. A comparison of the effect of refresh plus and bion tears on dry eye symptoms and ocular surface health in myopic LASIK patients. CLAOJ. 2002;28(2): 96-100.

72. Perry H, Doshi-Carnevale S, Donnenfeld ED, Solomon R, Biser SA, Bloom AH. Efficacy of commercially available topical cyclospoine A $0.05 \%$ in the treatment of meibomian gland dysfunction. Cornea. 2006;25(2):171-175.

73. Bron AJ, Daubas P, Siou-Mermet R, Trinquand C. Comparison of the efficacy and safety of two eye gels in the treatment of dry eyes: Lacrinorm and Viscotears. Eye (Lond). 1998;12(Pt 5): 839-847.

74. Dumbleton K, Woods C, Fonn D. An investigation of the efficacy of a novel ocular lubricant. Eye Contact Lens. 2009;35(3):149-155.

75. Garcia-Lázaro S, Belda-Salmerón L, Ferrer-Blasco T, Cerviño A, Montés-Micó R. Comparison of two artificial tear formulations for dry eye through high-resolution optical coherence tomography. Clin Exp Optom. 2011;94(6):549-556.

76. Prabhasawat P, Tesavibul N, Kasetsuwan N. Performance profile of sodium hyaluronate in patients with lipid tear deficiency: randomised, double-blind, controlled, exploratory study. Br J Ophthalmol. 2007; 91(1):47-50.

77. Lee S, Dausch S, Maierhofer G, Dausch D. [A new therapy concept for the treatment of dry eye - the usefulness of phospholipid liposomes] Klin Monbl Augenheilkd. 2004;221(10):825-836.

78. Craig JP, Purslow C, Murphy PJ, Wolffsohn JS. Effect of a liposomal spray on the pre-ocular tear film. Cont Lens Anterior Eye. 2010;33(2): 83-87.

79. Jacobi C, Kruse FE, Cursiefen C. Prospective, randomized, controlled comparison of SYSTANE UD eye drops versus VISINE INTENSIV $1 \%$ EDO eye drops for the treatment of moderate dry eye. $J$ Ocul Pharmacol Ther. 2012;28(6):598-603.

80. Bhojwani R, Cellesi F, Maino A, Jalil A, Haider D, Noble B. Treatment of dry eye: an analysis of the British Sjögren's syndrome association comparing substitute tear viscosity and subjective efficacy. Cont Lens Anterior Eye. 2011;34(6):269-273.

81. Marner K, Møoller PM, Dillon M, Rask-Pedersen E. Viscous carbomer eye drops in patients with dry eyes. Efficacy and safety. A randomized, open, cross-over, multicentre study. Acta Ophthalmol Scand. 1996; 74(3):249-252.

82. Vehige J, et al. Use of a new non-preserved artificial tear for dry eye treatment after LASIK surgery. Am Academy of Optometry. 2009; $\mathrm{CN}-00746208$.

83. Sindt CW, Foulks GN. Efficacy of an artificial tear emulsion in patients with dry eye associated with meibomian gland dysfunction. Clin $\mathrm{Oph}$ thalmol. 2013;7:1713-1722.

84. Krader C. Drops decrease tear evaporation. Ophthalmology Times. April 2011. 
85. Christensen MT. Corneal staining reductions observed after treatment with Systane lubricant eye drops. Adv Ther. 2008;25(11):1191-1199.

86. Paugh JR, Nguyen AL, Huang P, Hwang JS. Retention and retention of effect of topical formulations in dry eye subjects. Optom Vis Sci. 2008;85(9):873-879.

87. Sánchez MA, Arriola-Villalobos P, Torralbo-Jiménez P, et al. The effect of preservative-free HP-Guar on dry eye after phacoemulsification: a flow cytometric study. Eye (Lond). 2010;24(8):1331-1337.

88. Versura P, Profazio V, Campos EC. One month use of Systane improves ocular surface parameters in subjects with moderate symptoms of ocular dryness. Clin Ophthalmol. 2008;2(3):629-635.
89. Durrie D, Stahl J. A randomized clinical evaluation of the safety of Systane Lubricant Eye Drops for the relief of dry eye symptoms following LASIK refractive surgery. Clin Ophthalmol. 2008;2(4): 973-979.

90. Montés-Micó R, Cerviño A, Ferrer-Blasco T, García-Lázaro S, OrtíNavarro S. Optical quality after instillation of eyedrops in dry-eye syndrome. J Cataract Refract Surg. 2010;36(6):935-940. 


\section{Supplementary materials}

Table SI Methylcellulose-based artificial tears commercially available

\begin{tabular}{|c|c|c|}
\hline Name & Active ingredients & Preservatives \\
\hline GenTeal ${ }^{\circledR}$ Mild & $0.2 \% \mathrm{HPMC}$ & GenAqua $^{\circledR}$ (sodium perborate) \\
\hline \multirow[t]{2}{*}{ GenTeal ${ }^{\otimes}$ Moderate to Severe } & $0.3 \%$ HPMC & GenAqua $^{\circledR}$ (sodium perborate) \\
\hline & $0.25 \% \mathrm{CMC}$ & \\
\hline Ultra Tears ${ }^{\circledR}$ & $0.3 \% \mathrm{HPMC}$ & BAK \\
\hline Tearisol ${ }^{\circledR}$ & $0.3 \% \mathrm{HPMC}$ & BAK \\
\hline Lacril $^{\circledR}$ & $0.5 \% \mathrm{HPMC}$ & Chlorobutonal \\
\hline Isopto ${ }^{\circledR}$ Alkaline & I.0\% HPMC & BAK \\
\hline Isopto ${ }^{\circledR}$ Plain & $0.5 \% \mathrm{HPMC}$ & BAK \\
\hline Isopto ${ }^{\circledR}$ Tears & $0.5 \% \mathrm{HPMC}$ & BAK \\
\hline Nature's Tears ${ }^{\circledR}$ & $0.4 \% \mathrm{HPMC}$ & BAK \\
\hline Natural Balance Tears & $0.4 \% \mathrm{HPMC}$ & BAK \\
\hline Rohto ${ }^{\circledR}$ Hydra & $0.3 \%$ HPMC & Polyaminopropyl biguanide \\
\hline \multirow[t]{2}{*}{ Thera Tears ${ }^{\circledR}$} & $0.25 \% \mathrm{CMC}$ & Preserved-form ${ }^{\mathrm{a}}$ \\
\hline & & Dequest (sodium perborate and phosphoric acid) \\
\hline Refresh Tears ${ }^{\circledR}$ & $0.5 \% \mathrm{CMC}$ & Purite (stabilized oxychloro complex) \\
\hline Refresh Plus $^{\circledR}$ & $0.5 \% \mathrm{CMC}$ & None \\
\hline \multirow[t]{2}{*}{ Refresh Celluvisc ${ }^{\circledR}$} & $1.0 \% \mathrm{CMC}$ & Preserved-form ${ }^{a}$ \\
\hline & & Purite (stabilized oxychloro complex) \\
\hline \multirow[t]{2}{*}{ Refresh Liquige $^{\circledast}$} & $1.0 \% \mathrm{CMC}$ & Preserved-form ${ }^{\mathrm{a}}$ \\
\hline & & Purite (stabilized oxychloro complex) \\
\hline Just Tears & $0.5 \% \mathrm{CMC}$ & Purite (stabilized oxychloro complex) \\
\hline
\end{tabular}

Notes: ${ }^{a}$ Both preserved and preservative-free formulations commercially available. Manufacturers are as follows: GenTeal ${ }^{\circledR}$, Novartis Pharmaceuticals, East Hanover, NJ, USA; Ultra Tears ${ }^{\circledR}$, Alcon Laboratories, Inc., Fort Worth, TX, USA; Teariso ${ }^{\circledR}$, Novartis Pharmaceuticals; Lacril ${ }^{\circledR}$, Allergan, Irvine, CA, USA; Isopto ${ }^{\circledR}$, Alcon Laboratories, Inc.; Nature's Tears ${ }^{\circledR}$, Bio-Logic Aqua Technologies, Grants Pass, OR, USA; Natural Balance Tears, Major Pharmaceuticals, Livonia, MI, USA; Rohto ${ }^{\circledR}$ Hydra, Rohto Laboratories Indonesia, Padalarang, Indonesia; Thera Tears ${ }^{\circledR}$, Advanced Vision Research, Ann Arbor, MI, USA; Refresh ${ }^{\circledR}$, Allergan; GenAqua ${ }^{\circledR}$, Novartis Ophthalmics, East Hanover, NJ, USA; Just Tears, Blairex, Columbus, IN, USA.

Abbreviations: BAK, benzalkonium chloride; CMC, carboxy methylcellulose; HPMC, hydroxypropyl methylcellulose.

Table S2 Polyvinyl alcohol-based artificial tears commercially available

\begin{tabular}{|c|c|c|}
\hline Name & Active ingredients & Preservatives \\
\hline Nutratear $^{\circledast}$ & $0.4 \%$ PVA & Polexitonium \\
\hline \multirow[t]{2}{*}{ Murine Tears ${ }^{\circledR}$} & $0.5 \%$ PVA & BAK \\
\hline & $0.6 \%$ povidone & \\
\hline Akorn ${ }^{\circledast}$ Artificial Tears & $1.4 \%$ PVA & BAK \\
\hline \multirow[t]{2}{*}{ MiniDrops ${ }^{\circledR}$} & I.4\% PVA & None \\
\hline & $0.6 \%$ providone & \\
\hline \multirow[t]{2}{*}{ Refresh Classic $^{\circledR}$} & I.4\% PVA & None \\
\hline & $0.4 \%$ povidone & \\
\hline \multirow[t]{2}{*}{ Clear Eyes ${ }^{\circledR}$ Artificial Tears } & $0.5 \%$ PVA & BAK \\
\hline & $0.6 \%$ povidone & \\
\hline \multirow[t]{2}{*}{ Freshkote ${ }^{\circledR}$} & $2.7 \%$ PVA & Polixetonium \\
\hline & $2.0 \%$ povidone & \\
\hline
\end{tabular}

Notes: Manufacturers are as follows: Nutratear ${ }^{\circledR}$, Medco Lab, Inc, Sioux City, IA, USA; Murine Tears ${ }^{\circledR}$, Prestige Brands Holdings, Inc., Tarrytown, NY, USA; Akorn ${ }^{\circledR}$, Akorn, Incorporated, Lake Forest, IL, USA; MiniDrops ${ }^{\circledR}$, Optics Laboratory, Inc., El Monte, CA, USA; Refresh ${ }^{\circledR}$, Allergan, Irvine, CA, USA; Clear Eyes ${ }^{\circledR}$, Prestige Brands Holdings, Inc., Tarrytown, NY, USA; Freshkote ${ }^{\circledast}$, FOCUS Laboratories, Inc., North Little Rock, AR, USA.

Abbreviations: BAK, benzalkonium chloride; PVA, polyvinyl alcohol. 
Table S3 Liquid polyol-based artificial tears available on the market

\begin{tabular}{|c|c|c|}
\hline Name & Active ingredients & Preservatives \\
\hline Oasis $^{\circledR}$ Tears & $0.2 \%$ glycerin $(15 \%)$ & No \\
\hline Oasis $^{\circledR}$ Tears Plus & $0.2 \%$ glycerin $(30 \%)$ & No \\
\hline Advanced Eye Relief ${ }^{\mathrm{TM}}$ "Environmental" & $1.0 \%$ glycerin & BAK \\
\hline \multirow[t]{2}{*}{ Advanced Eye Relief 'M "Rejuvenation" } & $0.3 \%$ glycerin & BAK \\
\hline & I.0\% propylene glycol & \\
\hline \multirow[t]{2}{*}{ Blink $^{\circledast}$ Tears } & $0.25 \%$ polyethylene glycol 400 & Preserved-form ${ }^{a}$ \\
\hline & Hyaluronic acid & OcuPure ${ }^{\circledR}$ (stabilized oxychloro complex) \\
\hline \multirow[t]{2}{*}{ Blink $^{\circledast}$ Gel Tears } & $0.25 \%$ polyethylene glycol 400 & OcuPure $^{\circledR}$ (stabilized oxychloro complex) \\
\hline & Hyaluronic acid & \\
\hline Systane ${ }^{\circledR}$ Balance & $0.6 \%$ propylene glycol & Polyquad ${ }^{\circledR}$ (polyquaternium-I) \\
\hline \multirow[t]{2}{*}{ Systane $^{\circledR}$ Gel Drops } & $0.4 \%$ polyethylene glycol 400 & Polyquad $^{\circledR}$ (polyquaternium-I) \\
\hline & $0.3 \%$ propylene glycol & \\
\hline \multirow[t]{2}{*}{ Systane ${ }^{\circledR}$} & $0.4 \%$ polyethylene glycol 400 & Preserved-form ${ }^{a}$ \\
\hline & $0.3 \%$ propylene glycol & Polyquad $^{\circledR}$ (polyquaternium-I) \\
\hline \multirow[t]{2}{*}{ Systane ${ }^{\circledR}$ Ultra } & $0.4 \%$ polyethylene glycol 400 & Preserved-form ${ }^{\mathrm{a}}$ \\
\hline & $0.3 \%$ propylene glycol & Polyquad $^{\circledR}$ (polyquaternium-I) \\
\hline \multirow[t]{2}{*}{ Soothe ${ }^{\circledR}$} & $0.6 \%$ glycerin & No \\
\hline & $0.6 \%$ propylene glycol & \\
\hline Viva Drops ${ }^{\circledR}$ & $1.0 \%$ polysorbate 80 & No \\
\hline
\end{tabular}

Notes: aBoth preserved and preservative-free formulations commercially available. Manufacturers are as follows: Oasis ${ }^{\circledR}$, Oasis Medical, Inc., Glendora, CA, USA; Advanced Eye Relief ${ }^{\mathrm{M}}$, Bausch \& Lomb Incorporated, Bridgewater, NJ, USA; Blink ${ }^{\circledast}$, Abbott Laboratories Inc., Abbott Park, Illinois, USA; Systane ${ }^{\circledR}$, Alcon Laboratories, Inc., Fort Worth, TX, USA; Soothe ${ }^{\circledast}$, Bausch \& Lomb Incorporated; Viva Drops ${ }^{\circledR}$, Dakota Laboratories, LLC, Mitchell, SD, USA; Polyquad ${ }^{\circledast}$, Alcon Laboratories, Inc.; OcuPure ${ }^{\circledR}$, Abbott Laboratories Inc.

Abbreviation: BAK, benzalkonium chloride.

Table S4 Gels, ointments, sprays, and an ophthalmic insert for dysfunctional tear syndrome

\begin{tabular}{|c|c|c|c|}
\hline Name & Active ingredients & Delivery & Preservatives \\
\hline \multirow[t]{2}{*}{ GenTea ${ }^{\circledR}$ Gel } & $0.3 \%$ HPMC & Gel & Preserved-forma \\
\hline & Carbopol 980 & & GenAqua $^{\circledR}$ \\
\hline Tears Again ${ }^{\circledR}$ Night \& Day Gel & $1.5 \%$ CMC & Gel & $\begin{array}{l}\text { Dissipate (stabilized } \\
\text { oxyborate complex) }\end{array}$ \\
\hline $\mathrm{Hylo}^{\circledR}$-Gel & $0.2 \%$ hyaluronic acid & Gel & None \\
\hline ViscoTears ${ }^{\circledR}$ Liquid Gel & $0.2 \%$ carbomer 980 & Gel & None \\
\hline Liquivisc $^{\text {TM }}$ & $0.25 \%$ carbomer $974 \mathrm{P}$ & Gel & BAK \\
\hline Liposic $^{\circledR}$ & $0.2 \%$ carbomer 980 & Gel & None \\
\hline \multirow[t]{2}{*}{ Soothe ${ }^{\circledast}$ Lubricant Eye Ointment } & $20 \%$ mineral oil & Ointment & None \\
\hline & $80 \%$ white petrolatum & & \\
\hline \multirow[t]{2}{*}{ Akwa $^{\circledR}$ Tears Ointment } & $15 \%$ mineral oil & Ointment & None \\
\hline & $83 \%$ white petrolatum & & \\
\hline \multirow{2}{*}{ Rugby ${ }^{\circledR}$ Artifical Tear Ointment } & $15 \%$ mineral oil & Ointment & None \\
\hline & $83 \%$ white petrolatum & & \\
\hline \multirow[t]{2}{*}{ Puralube ${ }^{\circledast}$ Ointment } & $15 \%$ mineral oil & Ointment & None \\
\hline & $85 \%$ white petrolatum & & \\
\hline \multirow[t]{2}{*}{ Lubrifresh $^{T M} P M$} & $15 \%$ mineral oil & Ointment & None \\
\hline & $83 \%$ white petrolatum & & \\
\hline \multirow[t]{2}{*}{ Refresh $\mathrm{PM}^{\circledR}$ Ointment } & $42.5 \%$ mineral oil & Ointment & None \\
\hline & $57.3 \%$ white petrolatum & & \\
\hline \multirow[t]{2}{*}{ Tears Naturale ${ }^{\circledR}$ PM } & $56.8 \%$ white petrolatum & Ointment & None \\
\hline & $42.5 \%$ mineral oil & & \\
\hline \multirow[t]{2}{*}{ Refresh Lacrilube ${ }^{\circledR}$} & $42.5 \%$ mineral oil & Ointment & Chlorobutanol \\
\hline & $56.8 \%$ white petrolatum & & \\
\hline \multirow[t]{2}{*}{ Systane ${ }^{\circledR}$ Nighttime Ointment } & $3 \%$ mineral oil & Ointment & None \\
\hline & $94 \%$ white petrolatum & & \\
\hline Clarymist $^{\mathrm{TM}}$ & $1.0 \%$ woy lecithin & Spray & Phenoxyethanol \\
\hline Actimist $^{\mathrm{TM}}$ & I\% woy Lecithin & Spray & Phenoxyethanol \\
\hline
\end{tabular}

(Continued) 
Table S4 (Continued)

\begin{tabular}{|c|c|c|c|}
\hline Name & Active ingredients & Delivery & Preservatives \\
\hline Tears Again $^{\circledR}$ & $1.4 \%$ PVA & Spray & Dissipate (stabilized \\
\hline Nature's Tears ${ }^{\circledR}$ & Bio-Logic Aqua ${ }^{\circledR}$ tissue-culture grade water & Spray & $\begin{array}{l}\text { oxyborate complex) } \\
\text { None }\end{array}$ \\
\hline Vizulize Dry Eyes Eye Mist & $0.10 \%$ hyaluronate & Spray & $\mathrm{N}-\mathrm{IG}$ \\
\hline Lacrisert $^{\circledR, b}$ & 5 mg HPMC & Insert & None \\
\hline
\end{tabular}

Notes: ${ }^{a}$ Both preserved and preservative-free formulations commercially available; 'Prescription-only ophthalmic insert. Manufacturers are as follows: GenTeal ${ }^{\circledR}$, Novartis Pharmaceuticals, East Hanover, NJ, USA; Tears Again ${ }^{\circledast}$, OcuSoft, Rosenberg, TX, USA; Hylo ${ }^{\circledR}$-Gel, URSAPHARM, Saarbrücken, Germany; Viscotears ${ }^{\circledR}$, Novartis Pharmaceuticals; Liquivisc ${ }^{T M}$, URSAPHARM; Liposic ${ }^{\circledR}$, Bausch \& Lomb Incorporated, Bridgewater, NJ, USA; Soothe ${ }^{\circledast}$, Bausch \& Lomb Incorporated; Akwa ${ }^{\circledR}$, Akorn, Incorporated, Lake Forest, IL, USA; Rugby ${ }^{\circledR}$, Rugby Laboratories, Livonia, MI, USA; Puralube ${ }^{\circledR}$, Fougera Pharmaceuticals Inc., Melville, NY, USA; Lubrifresh ${ }^{\top M}$, Major Pharmaceuticals, Livonia, MI, USA; Refresh ${ }^{\circledR}$, Allergan, Irvine, CA, USA; Systane ${ }^{\circledR}$, Alcon Laboratories, Inc., Fort Worth, TX, USA; Clarymist ${ }^{\mathrm{TM}}$, Savant Distribution, Leeds, UK; Actimist ${ }^{\mathrm{TM}}$, Reckitt Benckiser plc, Berkshire, UK; Nature’s Tears $^{\circledR}$, Bio-Logic Aqua Technologies, Grants Pass, OR, USA; Lacrisert ${ }^{\circledR}$, Valeant Pharmaceuticals North America LLC, Bridgewater, NJ, USA; GenAqua ${ }^{\circledR}$, Novartis Ophthalmics, East Hanover, NJ, USA; Tears Again ${ }^{\circledR}$, OcuSoft; Vizulize Dry Eyes Eye Mist, Butterflies Healthcare, Banbury, OX, UK; Bio-Logic Aqua ${ }^{\circledR}$, Bio-Logic Aqua Technologies.

Abbreviations: BAK, benzalkonium chloride; CMC, carboxy methylcellulose; HPMC, hydroxypropyl methylcellulose; N-IG, N-hydroxymethylglycinate; PVA, polyvinyl alcohol.

Table S5 Artificial tears with combinations of active ingredients

\begin{tabular}{|c|c|c|}
\hline Name & Active ingredients & Preservatives \\
\hline \multirow[t]{3}{*}{ Refresh Optive ${ }^{\circledast}$ Advanced } & $0.5 \%$ CMC & Preserved-form ${ }^{a}$ \\
\hline & $1.0 \%$ glycerine & Purite $^{\circledR}$ (stabilized oxychloro complex) \\
\hline & $0.5 \%$ polysorbate 80 & \\
\hline Refresh Optive $^{\circledR}$ & $0.5 \% \mathrm{CMC}$ & Preserved-form ${ }^{a}$ \\
\hline Refresh Optive ${ }^{\circledast}$ Sensitive & $\begin{array}{l}0.9 \% \text { glycerine } \\
0.5 \% \text { CMC }\end{array}$ & $\begin{array}{l}\text { Purite }^{\circledast} \text { (stabilized oxychloro complex) } \\
\text { None }\end{array}$ \\
\hline Tears Naturale ${ }^{\circledR}$ II & $\begin{array}{l}0.9 \% \text { glycerine } \\
0.3 \% \text { HPMC }\end{array}$ & Polyquad ${ }^{\circledR}$ (polyquaternium-I) \\
\hline Tears Naturale ${ }^{\circledR}$ Free & $\begin{array}{l}0.1 \% \text { dextran } 70 \\
0.3 \% \text { HPMC }\end{array}$ & None \\
\hline \multirow[t]{2}{*}{ Tears Naturale ${ }^{\circledast}$ Forte } & $\begin{array}{l}0.1 \% \text { dextran } 70 \\
0.3 \% \text { HPMC }\end{array}$ & Polyquad ${ }^{\circledR}$ (polyquaternium-I) \\
\hline & $0.1 \%$ dextran 70 & \\
\hline \multirow[t]{3}{*}{ Tears Naturale ${ }^{\circledR}$ - Bion Tears } & $\begin{array}{l}0.2 \% \text { glycerin } \\
0.3 \% \text { HPMC }\end{array}$ & None \\
\hline & $0.1 \%$ dextran 70 & \\
\hline & Zinc + bicarbonate & \\
\hline Tears Renewed ${ }^{\circledR}$ & $0.3 \% \mathrm{HPMC}$ & BAK \\
\hline Hypotears ${ }^{\circledR}$ & $\begin{array}{l}0.1 \% \text { dextran } 70 \\
1.0 \% \text { PVA }\end{array}$ & BAK \\
\hline \multirow[t]{2}{*}{ Soothe ${ }^{\circledR}$ XP } & $\begin{array}{l}\text { I. } 0 \% \text { polyethylene glycol } \\
\text { I\% light mineral oil }\end{array}$ & Polyhexamethylene biguanide \\
\hline & $4.5 \%$ mineral oil & \\
\hline Hylo ${ }^{\circledR}$-Fresh & $0.03 \%$ hyaluronic acid & None \\
\hline Hylo-Comod ${ }^{\circledR}$ & $0.1 \%$ hyaluronic acid & None \\
\hline \multirow[t]{3}{*}{ Similasan ${ }^{\circledR}$ Dry Eye Relief } & Belladonna & Silver sulfate \\
\hline & Euphrasia & \\
\hline & Mercurius sublimatus & \\
\hline \multirow[t]{3}{*}{ Similasan ${ }^{\circledR}$ Irritated Eye Relief } & Belladonna & Silver sulfate \\
\hline & Euphrasia & \\
\hline & Hepar sulfuris & \\
\hline
\end{tabular}

Notes: ${ }^{B}$ Both preserved and preservative-free formulations commercially available. Manufacturers are as follows: Refresh ${ }^{\circledast}$, Allergan, Irvine, CA, USA; Tears Naturale ${ }^{\circledast}$, Alcon Laboratories, Inc., Fort Worth, TX, USA; Tears Renewed ${ }^{\circledR}$, Akorn, Incorporated, Lake Forest, IL, USA; Hypotears ${ }^{\circledR}$, Novartis Pharmaceuticals, East Hanover, NJ, USA; Soothe ${ }^{\circledR}$, Bausch \& Lomb Incorporated, Bridgewater, NJ, USA; Hylo ${ }^{\circledR}$-Fresh and Hylo-Comod ${ }^{\circledR}$, URSAPHARM, Saarbrücken, Germany; Similasan ${ }^{\circledR}$, Similasan Corporation, Highlands Ranch, CO, USA; Polyquad ${ }^{\circledR}$, Alcon Laboratories, Inc.; Purite ${ }^{\circledR}$, Bio-Cide International Inc., Norman, OK, USA.

Abbreviations: BAK, benzalkonium chloride; CMC, carboxy methylcellulose; HPMC, hydroxypropyl methylcellulose; PVA, polyvinyl alcohol.

Clinical Ophthalmology

\section{Publish your work in this journal}

Clinical Ophthalmology is an international, peer-reviewed journal covering all subspecialties within ophthalmology. Key topics include: Optometry; Visual science; Pharmacology and drug therapy in eye diseases; Basic Sciences; Primary and Secondary eye care; Patien Safety and Quality of Care Improvements. This journal is indexed on

Submit your manuscript here: http://www.dovepress.com/clinical-ophthalmology-journal

\section{Dovepress}

PubMed Central and CAS, and is the official journal of The Society of Clinical Ophthalmology (SCO). The manuscript management system is completely online and includes a very quick and fair peer-review system, which is all easy to use. Visit http://www.dovepress.com/ testimonials.php to read real quotes from published authors. 